\title{
A comparative study on financially included and financially excluded farmers in Coimbatore district of Tamil Nadu
}

\author{
S. MENAKA, K. MANI AND R. SANGEETHA
}

Received : 21.01.2016; Revised : 23.02.2016; Accepted : 24.03.2016

\begin{abstract}
Financial inclusion was first featured - 2005 in India. 73 per cent of farmer households have no access to formal sources of credit from both formal/ informal sources. Of the total farmer households, only 27 per cent access formal sources of credit. Across regions, financial exclusion is more acute in Central, Eastern and North-Eastern regions. All three regions together accounted for 64 per cent of all financially excluded farmer households in the country.
\end{abstract}

KEY WORDS : Financial inclusion, Financial exclusion, Financial inclusive index, Kissan credit card, Cropping intensity

How to cite this paper : Menaka, S., Mani, K. and Sangeetha, R. (2016). A comparative study on financially included and financially excluded farmers in Coimbatore district of Tamil Nadu. Internat. J. Com. \& Bus. Manage, 9(1) : 73-76. 